OPEN ACCESS

Edited by:

Bin Tang,

Hangzhou Normal University, China

Reviewed by:

David Rivers,

Loyola University Maryland,

United States

Tong-Xian Liu,

Northwest A\&F University, China

${ }^{*}$ Correspondence:

Fanghao Wan

wanfanghao@caas.cn

Zhongshi Zhou

zhongshizhou@yahoo.com

Specialty section:

This article was submitted to Invertebrate Physiology, a section of the journal

Frontiers in Physiology

Received: 11 February 2018

Accepted: 08 June 2018

Published: 06 July 2018

Citation:

Chen H, Solangi GS, Guo J, Wan F and Zhou Z (2018) Antioxidant

Responses of Ragweed Leaf Beetle Ophraella communa (Coleoptera:

Chrysomelidae) Exposed to Thermal

Stress. Front. Physiol. 9:808. doi: 10.3389/fphys.2018.00808

\section{Antioxidant Responses of Ragweed Leaf Beetle Ophraella communa (Coleoptera: Chrysomelidae) Exposed to Thermal Stress}

\author{
Hongsong Chen 1,2, Ghulam Sarwar Solangi ${ }^{3}$, Jianying Guo ${ }^{1}$, Fanghao Wan ${ }^{1 *}$ and \\ Zhongshi Zhou ${ }^{1 *}$ \\ ${ }^{1}$ State Key Laboratory for Biology of Plant Diseases and Insect Pests, Institute of Plant Protection, Chinese Academy of \\ Agricultural Sciences, Beijing, China, ${ }^{2}$ Guangxi Key Laboratory for Biology of Crop Diseases and Insect Pests, Institute of \\ Plant Protection, Guangxi Academy of Agricultural Sciences, Nanning, China, ${ }^{3}$ Department of Entomology, Sindh Agriculture \\ University Subcampus, Umerkot, Pakistan
}

Ophraella communa LeSage is an effective biological control agent of common ragweed, Ambrosia artemisiifolia L., which competes with crops and causes allergic rhinitis and asthma. However, thermal stress negatively affects the developmental fitness and body size of this beetle. High temperatures cause a variety of physiological stress responses in insects, which can cause oxidative damage. We investigated the total protein content and activity of antioxidant enzymes including superoxide dismutase (SOD), catalase (CAT), and peroxidases (PODs) in 0 . communa adults when its different developmental stages were exposed to high temperatures $\left(40,42\right.$, and $\left.44^{\circ} \mathrm{C}\right)$ for $3 \mathrm{~h}$ each day for $3,5,5$, and 5 days, respectively (by stage), and a whole generation to high temperatures $\left(40,42\right.$, and $\left.44^{\circ} \mathrm{C}\right)$ for $3 \mathrm{~h}$ each day. A control group was reared at $28 \pm 2^{\circ} \mathrm{C}$. Under short-term daily phasic high-temperature stress, total protein contents were close to the control as a whole; overall, SOD activities increased significantly, CAT activities were closer to or even higher than the control, POD activities increased at $40^{\circ} \mathrm{C}$, decreased at 42 or $44^{\circ} \mathrm{C}$; stage-specific response was also observed. Under long-term daily phasic high-temperature stress, total protein content increased significantly at $44^{\circ} \mathrm{C}, \mathrm{SOD}$ activities increased at higher temperatures, decreased at $44^{\circ} \mathrm{C}$; CAT activities of females increased at $\leq 42^{\circ} \mathrm{C}$, and decreased at $44^{\circ} \mathrm{C}$, CAT activities of males decreased significantly; POD activities of females increased at $40^{\circ} \mathrm{C}$, decreased at $\geq 42^{\circ} \mathrm{C}, P O D$ activities of males decreased at $44^{\circ} \mathrm{C}$; and antioxidant enzymes activities in females were significantly higher than those in males. Antioxidative enzymes protect $O$. communa from oxidative damage caused by thermal stress.

Keywords: Ophraella communa, thermal stress, total protein, antioxidant enzymes activity, biological control

\section{INTRODUCTION}

Temperature is one of the most important environmental factors affecting life history, behavioral and physiological traits, population structure, and community composition in insects (Zhang et al., 2015b; Esperk et al., 2016). Insects have an optimal temperature range to which their biological functions are best adapted; over this range, insects might suffer physiological costs and 
fitness decrease (Jerbi-Elayed et al., 2015). Climate change has led to an increase in the frequency, intensity, and length of extreme high temperatures around the globe and this trend is expected to continue (Ma et al., 2018). In many parts of China, summer daily maximum temperatures in the field often exceed $40^{\circ} \mathrm{C}$ for several hours, and the number of such hot days has also increased in the last few years (Zhang et al., 2015b). Small insect herbivores often have short life cycles leading to overlapping generations, so any life stage may experience heat stress and the effects of heat stress also depend on heat stress (Zhao et al., 2017).

Thermal stress can result in oxidative damage and oxidative stress (Lopez-Martinez et al., 2008; Zhang et al., 2014). Oxidative stress refers to elevated intracellular levels of reactive oxygen species (ROS) that cause damage to lipids, proteins, and DNA (Schieber and Chandel, 2014). To prevent damage from ROS, insects have developed antioxidant defense mechanisms and these systems have both enzymatic and non-enzymatic components (Felton and Summers, 1995); antioxidant enzymes are key components in the regulation of intracellular ROS balance (Wang et al., 2012; Jia et al., 2014; Li et al., 2017). Major antioxidative enzymes in insects include superoxide dismutase (SOD), catalase (CAT), and peroxidases (POD) which are reported to be involved in insect defense systems (Zhang et al., 2015a; $\mathrm{Li}$ et al., 2017). SOD converts superoxide anion $\left(\mathrm{O}_{2}{ }^{-}\right)$into oxygen $\left(\mathrm{O}_{2}\right)$ and hydrogen peroxide $\left(\mathrm{H}_{2} \mathrm{O}_{2}\right)$, and CAT and POD break down hydrogen peroxide $\left(\mathrm{H}_{2} \mathrm{O}_{2}\right)$ into oxygen and water (Covarrubias et al., 2008; Li et al., 2017), which protect insects from oxidative damage.

Ophraella communa LeSage (Coleoptera: Chrysomelidae) is the best biological control agent of common ragweed, Ambrosia artemisiifolia L. (Asterales: Asteraceae) (Zhou et al., 2017). The larvae and adults of this leaf beetle feed on A. artemisiifolia leaves, destroying plants when its adults and larvae reach a high density, thus it performs a good control efficacy on A. artemisiifolia (Zhou et al., 2017). A. artemisiifolia is one of the most noxious weeds in agriculture around the world (Wan and Wang, 1988), due to its significantly negative effects on agricultural production, allergic rhinitis and asthma to human and impacts on biodiversity (Zhou et al., 2017). Research on O. communa has provided important insights into temperature. At constant temperature in the laboratory, the optimum developmental temperature for O. communa ranges from 25 to $28^{\circ} \mathrm{C}$, and temperatures not far beyond this range are harmful (Zhou et al., 2010); at $\geq 36^{\circ} \mathrm{C}$, all first-instar larvae are dead within $24 \mathrm{~h}$, and the survival of other instars and female fecundity decreases significantly (Zhou et al., 2010). Under brief heat stress, the pre-adult development and survival, adult survival, longevity, and fecundity of O. communa were all adversely affected by $2 \mathrm{~h}$ at $\geq 35^{\circ} \mathrm{C}$ (Zhou et al., 2011) or $3 \mathrm{~h}$ at $\geq 40^{\circ} \mathrm{C}$ (Chen et al. unpublished data), the body size of $O$. communa adults is also adversely affected after exposure of immature stages to $3 \mathrm{~h}$ at $\geq 40^{\circ} \mathrm{C}$ (Chen et al., 2014). However, the over $50 \%$ survival rates of eggs, pupae, and adults of O. communa exposure to $44^{\circ} \mathrm{C}$ for $3 \mathrm{~h}$ (Chen et al. unpublished data), the effective control of O. communa and Epiblema strenuana on A. artemisiifolia in the field in summer (Zhou et al., 2014) both indicate that $O$. communa has a large thermal tolerance plasticity. To date, the response of antioxidant enzymes in O. communa exposed to thermal stress has not been reported. The aim of the present study was to determine the effects of short-term and long-term phasic high-temperature exposure on the anti-oxidant enzymes activities of $O$. communa and identify the physiological repair responses to hot summer in the field.

\section{MATERIALS AND METHODS}

\section{Host Plants}

Ambrosia artemisiifolia seeds were collected from more than 10,000 plants from a field $\left(28^{\circ} 56^{\prime} 26^{\prime \prime} \mathrm{N}, 113^{\circ} 14^{\prime} 38^{\prime \prime} \mathrm{E}\right)$ near the town of Dajing, in Miluo county, Yueyang city, Hunan province, China, during late October 2010. The seeds were then stored at $4^{\circ} \mathrm{C}$. Adequately stored seeds were sown in a greenhouse at $28 \pm 2{ }^{\circ} \mathrm{C}$ under natural light at the Institute of Plant Protection, Hunan Academy of Agricultural Sciences $\left(25^{\circ} 21^{\prime} 18^{\prime \prime} \mathrm{N}, 114^{\circ} 33^{\prime} 40^{\prime \prime} \mathrm{E}\right)$, Changsha, Hunan province, China, in late March 2011. When seedlings reached a height of approximately $15 \mathrm{~cm}$, some of them were used in $O$. communa adult heat treatments. Apical buds of the remaining seedlings were removed to prevent apical dominance, and the seedlings were transplanted into pots $(21 \mathrm{~cm} \times 17 \mathrm{~cm})$ containing soil with one seedling per pot, a total of 1,000 common ragweed seedlings were prepared. All the plants were watered every day and fertilizer was applied $(\mathrm{N}: \mathrm{P}: \mathrm{K}=13: 7: 15)$ twice per month to maintain growth (Zhou et al., 2010). When the plants were approximately $40 \mathrm{~cm}$ high, approximately 400 of the potted plants were used for heat treatments of eggs, larvae, and pupae.

\section{Insect Culture}

More than 1,000 O. communa adults were collected from A. artemisiifolia plants in the same place for the plants in the previous subsection on June 24, 2011. Colonies of the beetle were maintained on $A$. artemisiifolia plants under natural light in the same greenhouse for the seedlings in the previous subsection.

Twelve pairs of $O$. communa adults were randomly collected from the rearing colony, and each individual was placed with the aid of a fine brush (size 0 ) onto a fresh common ragweed plant in a pot, which was then covered with nylon gauze (40 mesh size). After allowing two days for oviposition, the adult beetles were removed, the plants with newly eggs were placed in the greenhouse for normal growth until lots of the needed life stage emergence (such as eggs $\leq 12$-h old, first-instar larvae $\leq 24$-h old, pupae $\leq 24$-h old, adults $\leq 12$-h old)

\section{Heat Treatment Intensities and Durations}

The durations and intensities of our heat stress treatments were based on the duration and intensity of the highest temperatures in summer, which in central China is usually a few hours on any 1 day (maximum temperature of $44^{\circ} \mathrm{C}$ for approximately $3 \mathrm{~h}$ per day; Chen et al., 2014). Therefore, 40,42 , and $44^{\circ} \mathrm{C}$ for $3 \mathrm{~h}$ per day were selected, the treatment of $28^{\circ} \mathrm{C}$ was considered as control (Zhou et al., 2010). The exposure periods continue for 3-5 (one developmental stage) or over 20 (one generation) days based on the developmental periods of different developmental stages of $O$. communa (4.0 days for the egg, 7.6 days for the 
larva, and 6.0 days for the pupa) earlier recorded at a constant high temperature $\left(32^{\circ} \mathrm{C}\right.$ ) in laboratory (Zhou et al., 2010) and the number of hot days (daily maximum temperature $\geq 40^{\circ} \mathrm{C}$ ) at present and in the near future in China (Zhang et al., 2015b; Ma et al., 2018). The high-temperature exposures for each treatment were performed separately in environmental chambers (PRX450D, Ningbo Haishu Safe Experimental Equipment Co., Ltd., Zhejiang, China) at 28 (control), 40,42 , or $44 \pm 1^{\circ} \mathrm{C}$, with a relative humidity of $70 \pm 5 \%$, a photoperiod of $14: 10$ (L:D) h (Zhou et al., 2010), and a light intensity of 12,000 lx for $3 \mathrm{~h}$ daily. Each treatment was repeated three times.

\section{Short-Term Phasic Thermal Stress on Eggs, Larvae, Pupae, and Adults of O. communa}

The experiments were started in early July 2011. One hundred eggs $\leq 12$-h old, 100 first-instar larvae $\leq 24$-h old, and 50 pupae $\leq 24$-h old were separately retained on three potted plants in the greenhouse. Ten ragweed plants were randomly selected for each developmental stage, and they were then exposed to high temperatures for $3 \mathrm{~h}$ daily for 3,5 , and 5 consecutive days for eggs, larvae, and pupae in environmental chambers, respectively (by stage), after which the infested potted plants were kept in the greenhouse. A total of 120 ragweed plants were used.

Following high-temperature stress, treated pupae were collected by detaching the leaves they were on and placing the individual leaves into open transparent plastic boxes $(19 \mathrm{~cm} \times 12 \mathrm{~cm} \times 6 \mathrm{~cm})$ in an unsealed cuvette plastic tube covered with nylon gauze (60 mesh size) in the laboratory at $28 \pm 2^{\circ} \mathrm{C}$ and $70 \pm 5 \%$ relative humidity, where pupae were checked daily for adult emergence. The treated eggs and larvae were kept in the greenhouse until they reached the pupal stage. The process for these pupae was the same as that for the treated pupae following high-temperature stress. The sex of each newly emerged adult was determined with the help of stereo microscope. These adults were kept in the laboratory at $28 \pm 2{ }^{\circ} \mathrm{C}$ with relative humidity of $70 \pm 5 \%$ for 5 days.

Newly emerged adults $\leq 12$-h old (45 pairs) in the greenhouse culture were randomly selected for phasic high-temperature exposures. Fifteen pairs were placed on each of three fresh common ragweed seedlings $(15 \mathrm{~cm}$ height) potted in a plastic box $(19 \mathrm{~cm} \times 12 \mathrm{~cm} \times 6 \mathrm{~cm})$ with a hole $(15 \mathrm{~cm} \times 4 \mathrm{~cm})$ and covered with nylon gauze (60 mesh size), and this constituted one replicate. Ragweed seedlings containing these adults were exposed to high temperatures in environmental chambers for $3 \mathrm{~h}$ daily for 5 consecutive days, after which the infested potted plants were kept in a greenhouse, and a total of 36 ragweed plants were used.

\section{Long-Term Phasic Thermal Stress on O. communa}

The experiments were also started in early July 2011. Approximately 1,000 eggs $\leq 12$-h old in the greenhouse were retained on one potted plant. Ten potted plants were selected for each treatment temperature, and they were then exposed to the high-temperature treatments in environmental chambers for $3 \mathrm{~h}$ daily until the emergence of the adult. After which the infested potted plants were kept in a greenhouse, and a total of 40 ragweed plants were used. Fifteen pairs of newly emerged adults $\leq 12$-h old were placed on three fresh common ragweed seedlings (15 cm height) potted in a plastic box $(19 \mathrm{~cm} \times 12 \mathrm{~cm} \times 6 \mathrm{~cm})$ with a hole $(15 \mathrm{~cm} \times 4 \mathrm{~cm})$ and covered with nylon gauze (60 mesh size), and this constituted one replicate. The $O$. communa adults on ragweed seedlings were then exposed to high temperatures in the environmental chambers for $3 \mathrm{~h}$ daily for 5 consecutive days, after which the infested potted plants were kept in a greenhouse, and a total of 36 ragweed plants were used.

\section{Total Protein Content and Enzymes Activity Assays of 0 . communa}

After exposure to high temperatures, the total protein content and antioxidant enzyme activity in subsequent adults were determined. The protein extraction protocols were carried out according to a total protein quantitative assay (A045-2, Nanjing Jiancheng Bioengineering Institute, Nanjing, China). Protein concentrations were determined according to the Bradford (1976) method with bovine serum albumin as the standard.

The activities of SOD, CAT, and POD were examined using commercially available assay kits (A001-1-1, A007-1-1, A0841, Nanjing Jiancheng Bioengineering Institute, Nanjing, China) following the manufacturer's protocols.

Superoxide dismutase activity was measured spectrophotometrically at $550 \mathrm{~nm}$ by xanthine and xanthine oxidase systems. One unit of SOD activity was defined as the amount of enzyme required to cause $50 \%$ inhibition of the xanthine oxidase system reaction in $1 \mathrm{ml}$ enzyme extract with $1 \mathrm{mg}$ protein ( $\mathrm{U} \mathrm{mg} \mathrm{mg}^{-1}$ protein). CAT activity was determined spectrophotometrically at $405 \mathrm{~nm}$ by measuring the decrease of $\mathrm{H}_{2} \mathrm{O}_{2}$ due to hydrogen peroxide decomposition. One unit of CAT activity was defined as the amount that decomposes $1 \mu \mathrm{mol}$ of $\mathrm{H}_{2} \mathrm{O}_{2}$ per second per $\mathrm{mg}$ protein $\left(\mathrm{U} \mathrm{mg}^{-1}\right.$ protein). POD activity was determined at $420 \mathrm{~nm}$ by catalyzing the oxidation of a substrate in the presence of $\mathrm{H}_{2} \mathrm{O}_{2}$. One unit of POD activity was defined as the amount that catalyzes $1 \mu \mathrm{g}$ substrate per minute per mg protein ( $\mathrm{U} \mathrm{mg}^{-1}$ protein; Jia et al., 2011).

\section{Statistical Analyses}

All data were analyzed using SPSS 21.0 (SPSS Inc., Chicago, IL, United States). Means were separated using Tukey's honestly significant difference (HSD) test (one-way ANOVA) when significant differences were found at $P<0.05$ and were denoted as the means $\pm \mathrm{SE}$ (standard error of the mean).

\section{RESULTS}

\section{Total Protein Content}

First, in order to assay the antioxidant enzymes activities after exposure of different developmental stages or whole generation to phasic high temperatures, we evaluated the total protein content in subsequent adults. Total protein contents 
in $O$. communa females were significantly affected by the previous exposure of larvae $\left(F_{3,8}=52.31, P<0.0001\right)$, pupae $\left(F_{3,8}=85.78, P<0.0001\right)$, and adults $\left(F_{3,8}=434.51, P=0.0007\right)$ to phasic high temperatures, except for eggs $\left(F_{3,8}=3.83\right.$, $P=0.0571)$; the total protein contents were stage-specific when different developmental stages were exposed to any phasic high temperature compared to the control (Table 1). Total protein contents in $O$. communa males were also significantly affected by the previous exposure of eggs $\left(F_{3,8}=53.87, P<0.0001\right)$, larvae $\left(F_{3,8}=48.83, P<0.0001\right)$, pupae $\left(F_{3,8}=5.85, P=0.0205\right)$, and adults $\left(F_{3,8}=32.49, P=0.0001\right)$ to phasic high temperatures; the total protein contents were stage-specific when different developmental stages were exposed to 40 or $42^{\circ} \mathrm{C}$ for $3 \mathrm{~h}$ compared to the control and $44^{\circ} \mathrm{C}$ (Table 2).

After long-term phasic thermal stress, the total protein contents of $O$. communa female $\left(F_{3,8}=10.83, P=0.0007\right)$ and male $\left(F_{3,8}=20.50, P=0.0004\right)$ adults were significantly affected (Figure 1A). Total protein content of female adults significantly increased when exposed to $44^{\circ} \mathrm{C}$, and male adults showed significantly increased content at 42 and $44^{\circ} \mathrm{C}$, compared with the controls. No significant difference was observed in female adults between the $42^{\circ} \mathrm{C}$ and control conditions, or in male adults between the $40^{\circ} \mathrm{C}$ and control conditions (Figure 1A).

Taken together, these results suggest total protein contents in subsequent adults were significantly affected by the previous exposure of different developmental stages or whole generation to brief high temperatures.

\section{Antioxidative Enzymes Activity}

Next, we measured the antioxidant enzymes activities of O. communa adults after exposure of different developmental stages or whole generation to short- and long-term phasic high temperatures. In total, SOD activities of O. communa females increased after exposure of different developmental stages to phasic high temperatures $(P<0.05)$ compared to the control; the SOD activities were also stage-specific when different developmental stages were exposed to any phasic high temperature $(P<0.05)$ compared to the control (Table 3$)$. The SOD activities of O. communa males also increased significantly by the previous exposure of eggs $\left(F_{3,8}=33.2, P<0.0001\right)$, larvae $\left(F_{3,8}=240.02, P<0.0001\right)$, and adults $\left(F_{3,8}=23.07, P=0.0003\right)$ to phasic high temperatures, but the result for pupae is opposite $\left(F_{3,8}=7.91, P=0.0089\right)$; the stage-specific responses were also observed when different developmental stages were exposed to any phasic high temperature compared to the control (Table 4).

After long-term phasic thermal stress, the SOD activities of both $O$. communa female and male adults increased at higher temperatures (females at 40 or $42^{\circ} \mathrm{C}$, males at $40^{\circ} \mathrm{C}$ ), decreased at the highest temperature (Figure 1B). SOD activities of female adults were significantly higher than those of males both at high temperatures and $28^{\circ} \mathrm{C}$ (Figure 1B).

Overall, the CAT activities in $O$. communa adults were closer to or even higher than the control after exposure of different developmental stages to phasic high temperatures; the stage-specific responses were also observed when different developmental stages were exposed to any phasic high temperature compared to the control (Tables 5, 6).

After long-term phasic thermal stress, the CAT activities of O. communa female adults increased at 40 and $42^{\circ} \mathrm{C}$, decreased at $44^{\circ} \mathrm{C}\left(F_{3,8}=34.45, P<0.0001\right)$; the CAT activities of male adults decreased significantly at high temperatures compared to the control $\left(F_{3,8}=5.52, P=0.0238\right)$; higher CAT activities were observed in female adults than those of males both at high temperatures and control (Figure 1C).

TABLE 1 | Mean ( \pm SE) protein content of 0 . communa female adults when eggs, larvae, pupae, and adults were exposed for $3 \mathrm{~h}$ each day for 3,5 , 5 , and 5 days, respectively (by stage), to 28 (control), 40,42 , and $44^{\circ} \mathrm{C}$.

\begin{tabular}{|c|c|c|c|c|}
\hline \multirow[t]{2}{*}{ Temperature $\left({ }^{\circ} \mathrm{C}\right)$} & \multicolumn{4}{|c|}{ Protein content $\left(\mathrm{mg} \cdot \mathrm{L}^{-1}\right)$} \\
\hline & Eggs & Larvae & Pupae & Adults \\
\hline 28 & $3.3 \pm 0.2 \mathrm{a}, \mathrm{A}$ & $3.5 \pm 0.1 \mathrm{a}, \mathrm{A}$ & $3.6 \pm 0.1 b, A$ & $3.5 \pm 0.0 b, A$ \\
\hline 40 & $2.8 \pm 0.1 b, B$ & $2.0 \pm 0.1 \mathrm{~d}, \mathrm{C}$ & $5.3 \pm 0.2 \mathrm{a}, \mathrm{A}$ & $1.7 \pm 0.1 \mathrm{c}, \mathrm{C}$ \\
\hline 42 & $3.3 \pm 0.2 \mathrm{a}, \mathrm{B}$ & $3.0 \pm 0.1 b, B$ & $2.3 \pm 0.1 d, C$ & $4.2 \pm 0.1 \mathrm{a}, \mathrm{A}$ \\
\hline 44 & $3.4 \pm 0.1 \mathrm{a}, \mathrm{A}$ & $3.5 \pm 0.0 \mathrm{a}, \mathrm{A}$ & $2.8 \pm 0.2 c, B$ & $3.5 \pm 0.1 b, A$ \\
\hline
\end{tabular}

Values within the same column followed by different lowercase and uppercase letters within the same row are significantly different (Tukey's HSD test, $P$ < 0.05 ).

TABLE 2 | Mean ( \pm SE) protein content of 0 . communa male adults when eggs, larvae, pupae, and adults were exposed for 3 h each day for 3,5 , 5 , and 5 days, respectively (by stage), to 28 (control), 40,42 , and $44^{\circ} \mathrm{C}$.

\begin{tabular}{|c|c|c|c|c|}
\hline \multirow[t]{2}{*}{ Temperature $\left({ }^{\circ} \mathrm{C}\right)$} & \multicolumn{4}{|c|}{ Protein content $\left(\mathrm{mg} \cdot \mathrm{L}^{-1}\right)$} \\
\hline & Eggs & Larvae & Pupae & Adults \\
\hline 28 & $3.3 \pm 0.2 a, B$ & $3.4 \pm 0.1 \mathrm{a}, \mathrm{AB}$ & $3.8 \pm 0.2 \mathrm{ab}, \mathrm{A}$ & $3.2 \pm 0.1 a, B$ \\
\hline 40 & $3.4 \pm 0.1 a, A$ & $3.4 \pm 0.1 a, A$ & $3.3 \pm 0.1 \mathrm{bc}, \mathrm{A}$ & $3.2 \pm 0.1 \mathrm{a}, \mathrm{A}$ \\
\hline 42 & $1.3 \pm 0.1 \mathrm{c}, \mathrm{D}$ & $3.5 \pm 0.1 a, B$ & $4.0 \pm 0.2 a, A$ & $2.1 \pm 0.1 b, C$ \\
\hline 44 & $2.7 \pm 0.2 b, B$ & $2.0 \pm 0.1 b, C$ & $3.2 \pm 0.1 c, A$ & $3.4 \pm 0.1 \mathrm{a}, \mathrm{A}$ \\
\hline
\end{tabular}

Values within the same column followed by different lowercase and uppercase letters within the same row are significantly different (Tukey's HSD test, $P<0.05$ ). 

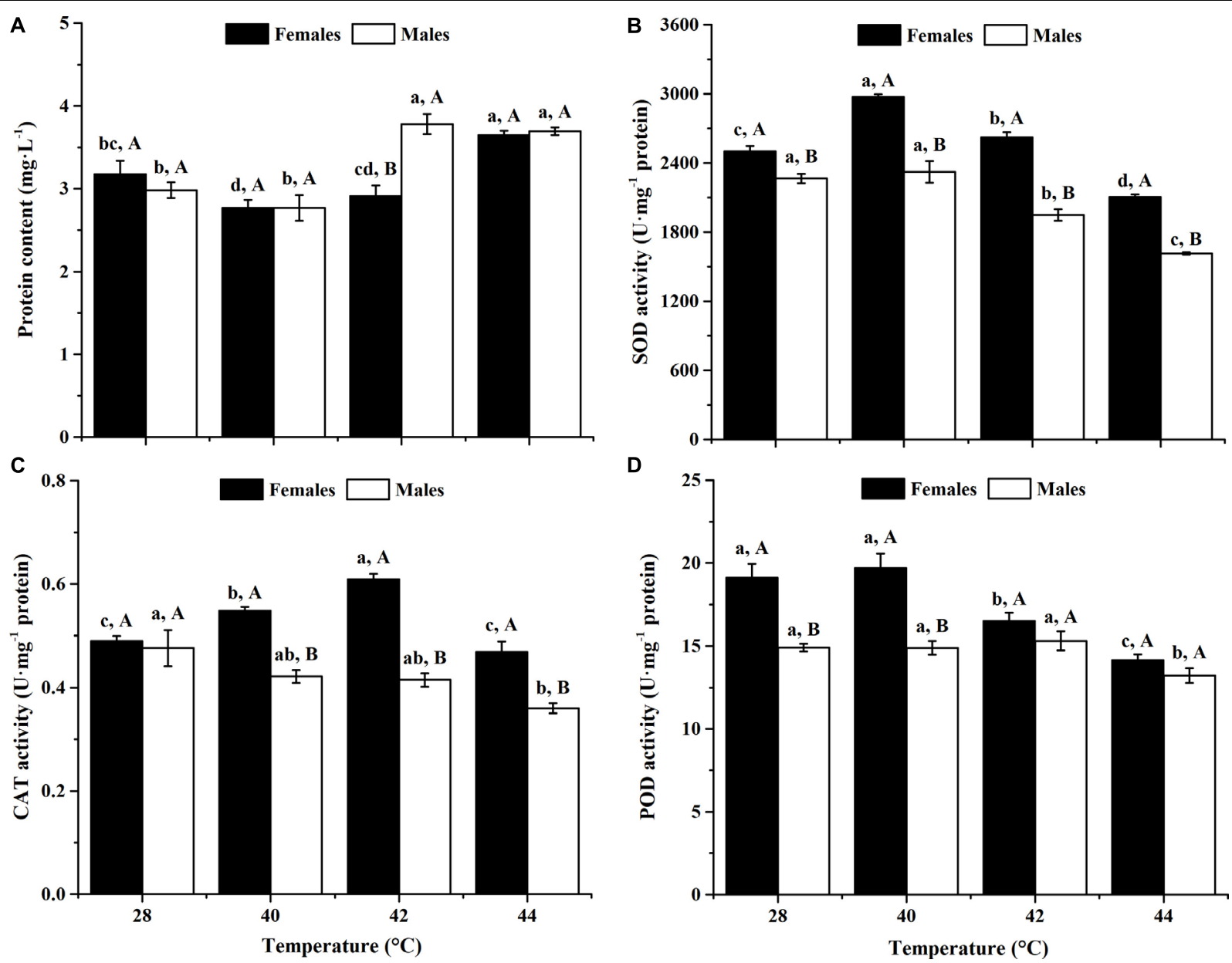

FIGURE 1 | Effect of long-term phasic thermal stress (12-h-old eggs to 5-days-old adults) on protein content and antioxidant enzyme activities of O. communa adults. The temperature $28^{\circ} \mathrm{C}$ served as a control. Each value represents the mean ( $\pm \mathrm{SE}$ ) in adult females (black bars) and males (white bars). Different lowercase letters indicate significant differences among heat treatments for the same gender. Different uppercase letters indicate significant differences between males and females at the same temperature (Tukey's HSD test, $P<0.05)$. (A) Protein content. (B) Superoxide dismutase (SOD) activity. (C) Catalase (CAT) activity. (D) Peroxidase (POD) activity.

TABLE 3 | Mean ( \pm SE) SOD activity of 0 . communa female adults when eggs, larvae, pupae, and adults were exposed for $3 \mathrm{~h}$ each day for 3,5 , 5 , and 5 days, respectively (by stage), to 28 (control), 40,42 , and $44^{\circ} \mathrm{C}$.

\begin{tabular}{|c|c|c|c|c|}
\hline \multirow[t]{2}{*}{ Temperature $\left({ }^{\circ} \mathrm{C}\right)$} & \multicolumn{4}{|c|}{ SOD activity (U $\mathrm{mg}^{-1}$ protein) } \\
\hline & Eggs & Larvae & Pupae & Adults \\
\hline 28 & $2549 \pm 68 b, A$ & $2493 \pm 97 b, A$ & $2547 \pm 48 b, A$ & $2495 \pm 55 b, A$ \\
\hline 40 & $2709 \pm 9 a b, B C$ & $2814 \pm 31 a, B$ & $2675 \pm 45 b, C$ & $4385 \pm 42 \mathrm{a}, \mathrm{A}$ \\
\hline 42 & $2725 \pm 44 a, B$ & $2629 \pm 41 a b, B$ & $3329 \pm 41 \mathrm{a}, \mathrm{A}$ & $2087 \pm 35 c, C$ \\
\hline 44 & $2271 \pm 66 c, B$ & $2530 \pm 37 b, A$ & $2643 \pm 34 b, A$ & $2170 \pm 53 c, B$ \\
\hline
\end{tabular}

Values within the same column followed by different lowercase and uppercase letters within the same row are significantly different (Tukey's HSD test, $P$ < 0.05).

Overall, the POD activities of both O. communa female and male adults increased at $40^{\circ} \mathrm{C}$, decreased at 42 or $44^{\circ} \mathrm{C}$; the stage-specific responses were also observed when different developmental stages were exposed to any phasic high temperature compared to the control (Tables 7, 8).

After long-term phasic thermal stress, the POD activities of O. communa female adults increased at $40^{\circ} \mathrm{C}$, decreased at 42 and $44^{\circ} \mathrm{C}\left(F_{3,8}=14.49, P=0.0013\right)$; the POD activities of male adults were close to the control at 40 and $42^{\circ} \mathrm{C}$, decreased at $44^{\circ} \mathrm{C}$ $\left(F_{3,8}=4.78, P=0.0341\right)$; higher POD activities were also observed in female adults than those of males both at high temperatures and control (Figure 1D).

Taken together, antioxidant enzymes (SOD, CAT, and POD) activities were observed for the first time to be 
TABLE 4 | Mean ( \pm SE) SOD activity of 0. communa male adults when eggs, larvae, pupae, and adults were exposed for 3 h each day for 3,5 , 5 , and 5 days, respectively (by stage), to 28 (control), 40,42 , and $44^{\circ} \mathrm{C}$.

\begin{tabular}{|c|c|c|c|c|}
\hline \multirow[t]{2}{*}{ Temperature $\left({ }^{\circ} \mathrm{C}\right)$} & \multicolumn{4}{|c|}{ SOD activity ( $\mathrm{U} \mathrm{mg}^{-1}$ protein) } \\
\hline & Eggs & Larvae & Pupae & Adults \\
\hline 28 & $2354 \pm 64 b, A$ & $2288 \pm 69 c, A$ & $2354 \pm 59 a, A$ & $2256 \pm 70 c, A$ \\
\hline 40 & $3010 \pm 95 a, A$ & $2456 \pm 46 b, B$ & $2144 \pm 49 a b, C$ & $2874 \pm 46 a, A$ \\
\hline 42 & $3160 \pm 74 a, B$ & $3750 \pm 27 a, A$ & $1982 \pm 106 b, D$ & $2270 \pm 84 c, C$ \\
\hline 44 & $2464 \pm 22 b, A$ & $2043 \pm 46 d, B$ & $1921 \pm 44 b, C$ & $2537 \pm 24 b, A$ \\
\hline
\end{tabular}

Values within the same column followed by different lowercase and uppercase letters within the same row are significantly different (Tukey's HSD test, $P$ < 0.05).

TABLE 5 | Mean ( \pm SE) CAT activity of 0 . communa female adults when eggs, larvae, pupae, and adults were exposed for $3 \mathrm{~h}$ each day for 3,5 , 5 , and 5 days, respectively (by stage), to 28 (control), 40,42 , and $44^{\circ} \mathrm{C}$.

\begin{tabular}{|c|c|c|c|c|}
\hline \multirow[t]{2}{*}{ Temperature $\left({ }^{\circ} \mathrm{C}\right)$} & \multicolumn{4}{|c|}{ CAT activity (U $\mathrm{mg}^{-1}$ protein) } \\
\hline & Eggs & Larvae & Pupae & Adults \\
\hline 28 & $0.50 \pm 0.02 b, A$ & $0.48 \pm 0.02 b, A$ & $0.51 \pm 0.02 b, A$ & $0.48 \pm 0.02 b, A$ \\
\hline 40 & $0.64 \pm 0.02 a, C$ & $0.81 \pm 0.02 a, B$ & $0.32 \pm 0.01 c, D$ & $1.08 \pm 0.08 a, A$ \\
\hline 42 & $0.45 \pm 0.01 b, B$ & $0.56 \pm 0.04 \mathrm{~b}, \mathrm{~A}$ & $0.62 \pm 0.01 \mathrm{a}, \mathrm{A}$ & $0.47 \pm 0.02 b, B$ \\
\hline 44 & $0.47 \pm 0.01 b, B$ & $0.55 \pm 0.03 b, A$ & $0.35 \pm 0.01 c, C$ & $0.49 \pm 0.01 b, B$ \\
\hline
\end{tabular}

Values within the same column followed by different lowercase and uppercase letters within the same row are significantly different (Tukey's HSD test, $P$ < 0.05).

TABLE 6 | Mean ( \pm SE) CAT activity of 0 . communa male adults when eggs, larvae, pupae, and adults were exposed for $3 \mathrm{~h}$ each day for 3,5 , 5 , and 5 days, respectively (by stage), to 28 (control), 40,42 , and $44^{\circ} \mathrm{C}$.

\begin{tabular}{|c|c|c|c|c|}
\hline \multirow[t]{2}{*}{ Temperature $\left({ }^{\circ} \mathrm{C}\right)$} & \multicolumn{4}{|c|}{ CAT activity (U $\mathrm{mg}^{-1}$ protein) } \\
\hline & Eggs & Larvae & Pupae & Adults \\
\hline 28 & $0.41 \pm 0.02 c, A$ & $0.44 \pm 0.04 b, A$ & $0.40 \pm 0.02 a, A$ & $0.41 \pm 0.01 \mathrm{c}, \mathrm{A}$ \\
\hline 40 & $1.04 \pm 0.05 a, A$ & $0.40 \pm 0.01 b c, C$ & $0.41 \pm 0.01 a, C$ & $0.58 \pm 0.03 a, B$ \\
\hline 42 & $0.47 \pm 0.01 \mathrm{bc}, \mathrm{C}$ & $0.80 \pm 0.01 \mathrm{a}, \mathrm{A}$ & $0.31 \pm 0.02 b, D$ & $0.52 \pm 0.01 b, B$ \\
\hline 44 & $0.54 \pm 0.01 b, A$ & $0.35 \pm 0.01 c, C$ & $0.40 \pm 0.01 a, B$ & $0.29 \pm 0.01 d, D$ \\
\hline
\end{tabular}

Values within the same column followed by different lowercase and uppercase letters within the same row are significantly different (Tukey's HSD test, $P$ < 0.05 ).

TABLE 7 | Mean ( \pm SE) POD activity of 0 . communa female adults when eggs, larvae, pupae, and adults were exposed for $3 \mathrm{~h}$ each day for 3,5 , 5 , and 5 days, respectively (by stage), to 28 (control), 40,42 , and $44^{\circ} \mathrm{C}$.

\begin{tabular}{|c|c|c|c|c|}
\hline \multirow[t]{2}{*}{ Temperature $\left({ }^{\circ} \mathrm{C}\right)$} & \multicolumn{4}{|c|}{ POD activity (U $\mathrm{mg}^{-1}$ protein) } \\
\hline & Eggs & Larvae & Pupae & Adults \\
\hline 28 & $18.20 \pm 2.11 \mathrm{a}, \mathrm{A}$ & $19.64 \pm 0.40 b, A$ & $18.81 \pm 0.94 a, A$ & $18.78 \pm 0.84 a, A$ \\
\hline 40 & $20.86 \pm 0.89 a, A B$ & $22.56 \pm 1.04 a, A$ & $19.21 \pm 0.61 a, B$ & $19.57 \pm 0.89 a, B$ \\
\hline 42 & $12.41 \pm 0.61 b, \mathrm{BC}$ & $13.35 \pm 0.56 c, B$ & $20.26 \pm 0.61 a, A$ & $10.57 \pm 0.71 b, C$ \\
\hline 44 & $12.27 \pm 0.56 b, B$ & $9.89 \pm 0.23 d, C$ & $15.43 \pm 0.48 b, A$ & $10.70 \pm 0.83 b, B C$ \\
\hline
\end{tabular}

Values within the same column followed by different lowercase and uppercase letters within the same row are significantly different (Tukey's HSD test, $P$ < 0.05).

sex-dependent - with few exceptions, enzyme activities were significantly higher in female adults than in male adults.

\section{DISCUSSION}

The effects of heat stress on insects depend on the frequency, amplitude, and duration of the stress (Ma et al., 2018), and the sex and developmental stage of the insect (Enriquez and Colinet, 2017). It is reported that the frequency, intensity, and length of heat hot days will increase in the short- and in the longterm (Ma et al., 2018). As an overlapping-generation species with a relatively short generation period (Zhou et al., 2010), any developmental stage or the whole generation of $O$. communa might encounter phasic high-temperature stress. The level of SOD, CAT, and POD activity in O. communa adults by the previous exposure of different developmental stages or whole generation to brief high temperatures increased, suggesting the defensive function of these enzymes in abating the adverse effect of ROS generated by the heat stress. 
TABLE 8 | Mean ( \pm SE) POD activity of 0 . communa male adults when eggs, larvae, pupae, and adults were exposed for 3 h each day for 3,5 , 5 , and 5 days, respectively (by stage), to 28 (control), 40,42 , and $44^{\circ} \mathrm{C}$.

\begin{tabular}{|c|c|c|c|c|}
\hline \multirow[t]{2}{*}{ Temperature $\left({ }^{\circ} \mathrm{C}\right)$} & \multicolumn{4}{|c|}{ POD activity ( $\mathrm{U} \mathrm{mg}^{-1}$ protein) } \\
\hline & Eggs & Larvae & Pupae & Adults \\
\hline 28 & $15.27 \pm 0.52 b, A$ & $16.48 \pm 0.45 a, A$ & $15.78 \pm 0.53 a, A$ & $14.81 \pm 0.87 a, A$ \\
\hline 40 & $19.32 \pm 1.29 a, A$ & $15.37 \pm 1.14 \mathrm{a}, \mathrm{BC}$ & $12.41 \pm 0.55 b, C$ & $16.45 \pm 0.6 a, A B$ \\
\hline 42 & $16.43 \pm 0.62 b, B$ & $25.39 \pm 1.2 \mathrm{a}, \mathrm{A}$ & $9.59 \pm 0.52 c, C$ & $11.59 \pm 0.6 b, C$ \\
\hline 44 & $9.67 \pm 0.4 c, B$ & $8.48 \pm 0.32 b, B$ & $8.8 \pm 0.28 c, B$ & $15.49 \pm 1.18 \mathrm{a}, \mathrm{A}$ \\
\hline
\end{tabular}

Values within the same column followed by different lowercase and uppercase letters within the same row are significantly different (Tukey's HSD test, $P$ < 0.05).

In the present study, we explored the effects of phasic and long-term daily thermal stress on total protein content and enzymatic antioxidant defense systems (SOD, CAT, and POD) of the common ragweed beetle, O. communa. Our results indicate that these parameters change significantly under different levels of phasic high temperature for 3-5 days, and under long-term high-temperature stress. Protein is reported as one of the major constituents imparting heat tolerance in the red flour beetle, Tribolium castaneum (Swetaleena et al., 2013). Overall, the total protein contents in $O$. communa adults at high temperatures similar with control $\left(28^{\circ} \mathrm{C}\right)$, under long-term thermal stress at $44^{\circ} \mathrm{C}$ even significantly higher than control $\left(28^{\circ} \mathrm{C}\right)$, which suggests that proteins protect $O$. communa from heat stress damage. The total protein content was found to increase with thermal stress, and this result is in accordance with a study conducted on T. castaneum (Swetaleena et al., 2013). By contrast, a study involving high-temperature treatments of $31^{\circ} \mathrm{C}$ reported that heat stress decreased protein contents in the termite Coptotermes formosanus (Tarver et al., 2012).

Superoxide dismutase is the most important antioxidant enzyme defense system against ROS, which catalyzes the breakdown of superoxide anions and transforms them into hydrogen peroxide and oxygen (Zelko et al., 2002). In the present study, the SOD activity in O. communa adult males and females increased significantly as a whole under short-term daily phasic high-temperature stress. Under long-term daily phasic hightemperature stress, the SOD activity in O. communa adult males and females increased at higher temperatures, decreased at $44^{\circ} \mathrm{C}$. These results suggest that the activity of SOD might be an adaptive response of different developmental stages $O$. communa to overcome high temperature $\leq 44^{\circ} \mathrm{C}$ induced ROS toxicity, using other superoxide anion scavenging pathways. A previous study indicated that SOD has an important role in reducing the high level of superoxide radicals induced by low or high temperatures (Celino et al., 2011). The increased activities of SOD under high temperature in our results are in accordance with studies of the role of SOD, in the antioxidant responses to thermal stress in the wolf spider, Xerolycosa nemoralis (Wilczek et al., 2013), cucumeris mite, Neoseiulus cucumeris (Zhang et al., 2014), and Propylaea japonica (Zhang et al., 2015a). SOD activity increased significantly at $39^{\circ} \mathrm{C}$, and markedly decreased at $41^{\circ} \mathrm{C}$ after exposure of $P$. japonica adults to heat stress for $1 \mathrm{~h}$ compared with control (Zhang et al., 2015a), which indicated that the activity of SOD was induced by moderate heat stress. A significant increase in SOD activities at 36 and $39^{\circ} \mathrm{C}$ for $1 \mathrm{~h}$ compared with control in Chilo suppressalis larvae was observed (Cui et al., 2011). SOD activity in the predatory mite N. cucumeris was significantly increased compared to the control at 35 and $38^{\circ} \mathrm{C}$ for $1-3 \mathrm{~h}$ (Zhang et al., 2014). Decreased SOD activity could also impair the $\mathrm{O}_{2}$-scavenging ability of the cells, thus favoring the accumulation of $\mathrm{O}_{2}$ and $\mathrm{H}_{2} \mathrm{O}_{2}$ (Jaleel et al., 2008), as SOD is the first and most important defense against ROS (Feng et al., 2015). Therefore, we hypothesized that SOD also plays a key role in the response of $O$. communa to short-term or long-term phasic thermal stress.

Catalase removes $\mathrm{H}_{2} \mathrm{O}_{2}$ only at high cellular concentrations and is inefficient at low concentrations (Yang et al., 2010). In this study, the CAT activities in O. communa adults were closer to or even higher than the control under short-term daily phasic high-temperature stress. Under long-term daily phasic hightemperature stress, the CAT activities of female O. communa adults increased at $\leq 42^{\circ} \mathrm{C}$, decreased at $44^{\circ} \mathrm{C}$, CAT activities of male O. communa adults decreased significantly. The present results are in accordance with a study which reported that CAT activity significantly increases at $35-41^{\circ} \mathrm{C}$ for $1 \mathrm{~h}$ in ladybeetle P. japonica adults (Zhang et al., 2015a). Increased CAT activity under thermal stress has also been reported in the oriental fruit fly Bactrocera dorsalis adults (Jia et al., 2011), and the fifth instar silkworm Bombyx mori (Nabizadeh and Kumar, 2011), the rice stem borer C. suppressalis larvae (Cui et al., 2011; Lu et al., 2017). These results suggest that CAT provides protection of $O$. communa under short-term or long-term phasic thermal stress $\leq 42^{\circ} \mathrm{C}$.

Peroxidase plays an important role in scavenging $\mathrm{H}_{2} \mathrm{O}_{2}$. Under short-term daily phasic high-temperature stress, POD activities increased at $40^{\circ} \mathrm{C}$, decreased at 42 or $44^{\circ} \mathrm{C}$. Under long-term daily phasic high-temperature stress, $\mathrm{POD}$ activities of female O. communa adults increased at $40^{\circ} \mathrm{C}$, decreased at $\geq 42^{\circ} \mathrm{C}$, POD activities of male communa adults decreased at $44^{\circ} \mathrm{C}$. These results are in accordance with POD activity increase in P. japonica adults at $41^{\circ} \mathrm{C}$ for $1 \mathrm{~h}$ (Zhang et al., 2015a), and B. dorsalis adult at $35-40^{\circ} \mathrm{C}$ for $3-6 \mathrm{~h}$ (Jia et al., 2011). In previous study, POD activity was significantly increased in N. cucumeris after heat shock for $1-2 \mathrm{~h}$ and decreased with the duration of exposure (Zhang et al., 2014). POD had an important role in the antioxidant response to thermal stress in P. japonica, and no significant difference in POD activity was found from 35 to $39^{\circ} \mathrm{C}$, whereas at $41^{\circ} \mathrm{C}$ a remarkable increase was observed, compared to the control (Zhang et al., 2015a). We hypothesized that POD also provides protection of $O$. communa under short-term or long-term phasic thermal stress $\leq 40^{\circ} \mathrm{C}$. 
In general, antioxidative enzymes (SOD, CAT, and POD) activity was found to be sex-dependent - it was higher in females than males. Overall, the higher antioxidative enzymes activity of O. communa females was obtained in the present study, which indicates higher thermal tolerance of female O. communa. A high body weight, large size, and high survival rate of O. communa females (Chen et al., 2014; Chen et al. unpublished data) may be closely related to the high antioxidative enzyme activity level of females under heat stress. The stage-specific thermal tolerance is very common in insects (Zhao et al., 2017), the stage-specific antioxidative enzyme activity was reported in C. suppressalis ( $\mathrm{Li}$ et al., 2017), and the stage-specific antioxidative enzyme activity of O. communa may be related to the sensitivity of stages to heat stress (Chen et al. unpublished data).

In conclusion, thermal stress is one of the factors that can generate oxidative stress products in O. communa. Hightemperature exposures cause oxidative stress at $44^{\circ} \mathrm{C}$ and changes in antioxidant enzymes (SOD, CAT, and POD) play an important part in reducing oxidative damage in O. communa up to $42^{\circ} \mathrm{C}$, the increased antioxidant defense systems of SOD, CAT, and POD may be an adaptive response of O. communa to avoid oxidative stress during exposure to high-temperature stress.

\section{REFERENCES}

Bradford, M. M. (1976). A rapid and sensitive method for the quantitation of microgram quantities of protein utilizing the principle of protein-dye binding. Anal. Biochem. 72, 248-254. doi: 10.1006/abio.1976.9999

Celino, F. T., Yamaguchi, S., Miura, C., Ohta, T., Tozawa, Y., Iwai, T., et al. (2011). Tolerance of spermatogonia to oxidative stress is due to high levels of $\mathrm{Zn}$ and $\mathrm{Cu} / \mathrm{Zn}$ superoxide dismutase. PLoS One 6:e16938. doi: 10.1371/journal.pone. 0016938

Chen, H. S., Zheng, X. W., Luo, M., Guo, J. Y., Luo, Y. H., Zhou, Z. S., et al. (2014). Effects of high temperature on body size and weight of Ophraella communa. Biocontrol Sci. Technol. 24, 882-890. doi: 10.1080/09583157.2014.90 2426

Covarrubias, L., Hernández-García, D., Schnabel, D., Salas-Vidal, E., and CastroObregón, S. (2008). Function of reactive oxygen species during animal development: passive or active? Dev. Biol. 320, 1-11. doi: 10.1016/j.ydbio.2008. 04.041

Cui, Y. D., Du, Y. Z., Lu, M. X., and Qiang, C. K. (2011). Antioxidant responses of Chilo suppressalis (Lepidoptera: Pyralidae) larvae exposed to thermal stress. J. Therm. Biol. 36, 292-297. doi: 10.1016/j.jtherbio.2011.04.003

Enriquez, T., and Colinet, H. (2017). Basal tolerance to heat and cold exposure of the spotted wing drosophila, Drosophila suzukii. Peer J. 5:e3112. doi: 10.7717/ peerj. 3112

Felton, G. W., and Summers, C. B. (1995). Antioxidant systems in insects. Arch. Insect Biochem. Physiol. 29, 187-197. doi: 10.1002/arch.940290208

Feng, Y. C., Liao, C. Y., Xia, W. K., Jiang, X. Z., Shang, F., Yuan, G. R., et al. (2015). Regulation of three isoforms of SOD gene by environmental stresses in citrus red mite, Panonychus citri. Exp. Appl. Acarol. 67, 49-63. doi: 10.1007/s10493015-9930-3

Esperk, T., Kjaersgaard, A., Walters, R. J., Berger, D., and Blanckenhorn, W. U. (2016). Plastic and evolutionary responses to heat stress in a temperate dung fly: negative correlation between basal and induced heat tolerance? J. Evol. Biol. 29, 900-915. doi: 10.1111/jeb.12832

Jaleel, C. A., Lakshmanan, G. M. A., Gomathinayagam, M., and Panneerselvam, R. (2008). Triadimefon induced salt stress tolerance in Withania somnifera and its relation-ship to antioxidant defense system. S. Afr. J. Bot. 74, 126-132. doi: 10.1016/j.sajb.2007.10.003

Jerbi-Elayed, M., Lebdi-Grissa, K., Foray, V., Muratori, F., and Hance, T. (2015). Using multiple traits to estimate the effects of heat shock on the fitness of Aphidius colemani. Entomol. Exp. Appl. 155, 18-27. doi: 10.1111/eea.12273

\section{AUTHOR CONTRIBUTIONS}

$\mathrm{ZZ}$ and FW conceived and designed the work. GS and JG contributed to the revision of the manuscript. HC performed the experiments and wrote the manuscript.

\section{FUNDING}

This work was supported by the National Natural Science Foundation of China for Excellent Young Scholars (No. 31322046) and National Natural Science Foundation of China (No. 31171908).

\section{ACKNOWLEDGMENTS}

We thank Wanmei Yang and Tianang Lei (Hunan Agricultural University) for their help during the experimental work. We also thank Springer Nature Author Services for editing the English of the manuscript.

Jia, F. X., Dou, W., Hu, F., and Wang, J. J. (2011). Effects of thermal stress on lipid peroxidation and antioxidant enzyme activities of oriental fruit fly, Bactrocera dorsalis (Diptera: Tephritidae). Fla. Entomol. 94, 956-963. doi: 10.1653/024.094. 0432

Jia, H. H., Sun, R. J., Shi, W. N., Yan, Y., Li, H., Guo, X. Q., et al. (2014). Characterization of a mitochondrial manganese superoxide dismutase gene from Apis cerana cerana and its role in oxidative stress. J. Insect Physiol. 60, 68-79. doi: 10.1016/j.jinsphys.2013.11.004

Li, Y., Zhao, Q., Duan, X., Song, C., and Chen, M. (2017). Transcription of four Rhopalosiphum padi (L.) heat shock protein genes and their responses to heat stress and insecticide exposure. Comp. Biochem. Physiol. A Mol. Integr. Physiol. 205, 48-57. doi: 10.1016/j.cbpa.2016.12.021

Lopez-Martinez, G., Elnitsky, M. A., Benoit, J. B., Lee, R. E., and Denlinger, D. L. (2008). High resistance to oxidative damage in the Antarctic midge Belgica antarctica, and developmentally linked expression of genes encoding superoxide dismutase, catalase and heat shock proteins. Insect Biochem. Mol. Biol. 38, 796-804. doi: 10.1016/j.ibmb.2008.05.006

Lu, Y. H., Bai, Q., Zheng, X. S., and Lu, Z. X. (2017). Expression and enzyme activity of catalase in Chilo suppressalis (Lepidoptera: Crambidae) is responsive to environmental stresses. J. Econ. Entomol. 110, 1803-1812. doi: 10.1093/jee/ tox 117

Ma, C. S., Wang, L., Zhang, W., and Rudolf, V. H. W. (2018). Resolving biological impacts of multiple heat waves: interaction of hot and recovery days. Oikos 127, 622-633. doi: 10.1111/oik.04699

Nabizadeh, P., and Kumar, T. S. J. (2011). Fat body catalase activity as a biochemical index for the recognition of thermotolerant breeds of mulberry silkworm, Bombyx mori L. J. Therm. Biol. 36, 1-6. doi: 10.1016/j.jtherbio.2010.08.008

Schieber, M., and Chandel, N. S. (2014). ROS function in redox signaling and oxidative stress. Curr. Biol. 24, R453-R462. doi: 10.1016/j.cub.2014.03.034

Swetaleena, T., Chellappan, M., and Ranjith, M. T. (2013). Characterization of heat shock protein in red flour beetle Tribolium castaneum Herbst. (Coleoptera: Tenebrionidae). Entomon 38, 27-38.

Tarver, M. R., Florane, C. B., Zhang, D., Grimm, C., and Lax, A. R. (2012). Methoprene and temperature effects on caste differentiation and protein composition in the Formosan subterranean termite, Coptotermes formosanus. J. Insect Sci. 12:18. doi: 10.1673/031.012.1801

Wan, F. H., and Wang, R. (1988). The occurrence and control of common ragweed in China. Bull. Agric. Sci. Techn. 5, 24-25.

Wang, Y., Wang, L. J., Zhu, Z. H., Ma, W. H., and Lei, C. L. (2012). The molecular characterization of antioxidant enzyme genes in Helicoverpa armigera adults 
and their involvement in response to ultraviolet-A stress. J. Insect Physiol. 58, 1250-1258. doi: 10.1016/j.jinsphys.2012.06.012

Wilczek, G., Babczyńska, A., and Wilczek, P. (2013). Antioxidative responses in females and males of the spider Xerolycosa nemoralis (Lycosidae) exposed to natural and anthropogenic stressors. Comp. Biochem. Physiol. C Toxicol. Pharmacol. 157, 119-131. doi: 10.1016/j.cbpc.2012.10.005

Yang, L. H., Huang, H., and Wang, J. J. (2010). Antioxidant responses of citrus red mite, Panonychus citri (McGregor) (Acari: Tetranychidae), exposed to thermal stress. J. Insect Physiol. 56, 1871-1876. doi: 10.1016/j.jinsphys.2010. 08.006

Zelko, I. N., Mariani, T. J., and Folz, R. J. (2002). Superoxide dismutase multigene family: a comparison of the CuZn-SOD (SOD1), Mn-SOD (SOD2), and ECSOD (SOD3) gene structures, evolution, and expression. Free Radic. Biol. Med. 33, 337-349. doi: 10.1016/S0891-5849(02)00905-X

Zhang, G. H., Liu, H., Wang, J. J., and Wang, Z. Y. (2014). Effects of thermal stress on lipid peroxidation and antioxidant enzyme activities of the predatory mite, Neoseiulus cucumeris (Acari: Phytoseiidae). Exp. Appl. Acarol. 64, 73-85. doi: 10.1007/s10493-014-9806-y

Zhang, S. Z., Fu, W. Y., Li, N., Zhang, F., and Liu, T. X. (2015a). Antioxidant responses of Propylaea japonica (Coleoptera: Coccinellidae) exposed to high temperature stress. J. Insect Physiol. 73, 47-52. doi: 10.1016/j.jinsphys.2015.0 1.004

Zhang, W., Chang, X. Q, Hoffmann, A. A., Zhang, S., and Ma, C. S. (2015b). Impact of hot events at different developmental stages of a moth: the closer to adult stage, the less reproductive output. Sci. Rep. 5:10436. doi: 10.1038/srep 10436

Zhao, F., Hoffmann, A. A., Xing, K., and Ma, C. S. (2017). Life stages of an aphid living under similar thermal conditions differ in thermal performance. J. Insect Physiol. 99, 1-7. doi: 10.1016/j.jinsphys.2017.03.003
Zhou, Z. S., Guo, J. Y, Chen, H. S., and Wan, F. H. (2010). Effects of temperature on survival, development, longevity, and fecundity of Ophraella communa (Coleoptera: Chrysomelidae), a potential biological control agent against Ambrosia artemisiifolia (Asterales: Asteraceae). Environ. Entomol. 39, 10211027. doi: 10.1603/EN09176

Zhou, Z. S., Guo, J. Y., Luo, M., and Wan, F. H. (2011). Effect of short-term high temperature stress on the development and fecundity of Ophraella communa (Coleoptera: Chrysomelidae). Biocontrol Sci. Technol. 21, 809-819. doi: 10. 1080/09583157.2011.584611

Zhou, Z. S., Chen, H. S., Zheng, X. W., Guo, J. Y., Guo, W., Li, M., et al. (2014). Control of the invasive weed Ambrosia artemisiifolia with Ophraella communa and Epiblema strenuana. Biocontrol Sci. Technol. 24, 950-964. doi: 10.1080/ 09583157.2014.897305

Zhou, Z. S., Wan, F. H., and Guo, J. Y. (2017). "Common ragweed Ambrosia artemisiifolia L.," in Biological Invasions and Its Management in China, Vol. 2, eds F. H. Wan, M. X. Jiang, and A. B. Zhan (New York, NY: Springer), 99-109. doi: 10.1007/978-981-10-3427-5_7

Conflict of Interest Statement: The authors declare that the research was conducted in the absence of any commercial or financial relationships that could be construed as a potential conflict of interest.

Copyright $\odot 2018$ Chen, Solangi, Guo, Wan and Zhou. This is an open-access article distributed under the terms of the Creative Commons Attribution License (CC BY). The use, distribution or reproduction in other forums is permitted, provided the original author(s) and the copyright owner(s) are credited and that the original publication in this journal is cited, in accordance with accepted academic practice. No use, distribution or reproduction is permitted which does not comply with these terms. 